\title{
An evaluation of Public servant awareness and use of GIS/Remote Sensing in Africa-Nigeria
}

\author{
Raimi Abidemi Asiyanbola \\ Department of Geography, Faculty of the Social Sciences, Osun State University, Osogbo, Osun \\ state, Nigeria, rasiyanbola@gmail.com
}

DOI: http://dx.doi.org/10.4314/sajg.v7i1.3

\begin{abstract}
The study evaluates awareness and use of Geographical Information Systems (GIS)/Remote Sensing by public servants in environmental related professions in Ibadan, Oyo State, Nigeria. The data used in this paper was collected through administration of 101 questionnaires to public servants in town planning, architecture, estate management and surveying in five local governments in Ibadan metropolitan area and at the Oyo State Government Secretariat between August and October, 2015. Frequencies, descriptive and inferential statistics which include Kolmogorov-Smirnov Test, ChiSquare test and correlation methods were used to analyze the data. Results indicated that majority of public servants in the selected professions were computer literate and had interest in GIS/remote sensing techniques and technologies. They were aware of the benefits than the costs of GIS/remote sensing techniques and technologies. Lack of time, inadequate finances, and lack of permission from the place of work were the three top constraints in building their GIS/remote sensing knowledge. The use of GIS/remote sensing applications was constrained by financial problems, followed by power supply (electricity) problem, lack of knowledge about GIS/remote sensing applications, lack of incentives/motivation, and technical nature of the applications.
\end{abstract}

Key words: Public servant, Geographical Information Systems (GIS), Remote Sensing, Human capacity building, Nigeria

\section{Introduction}

Scholarly literature shows that the areas in which GIS and remote sensing are applied are widespread (Heywood et al, 2006; ESRI, 2006; Dangermond, 2011; Coetzee et al., 2013; Mhangara and Odindi, 2013; Inggs, 2014; Woldai, 2014; Olwoch, 2014; Keita, 2014; Murwira, 2014, Bamutaze, 2014; Ademola, 2015): land use management, management of traffic, crime control, flood control, fire hazard control, hazardous materials, storm control, urban planning and management, tourism development and management, business and marketing analysis, etc. Consequently in various African countries, there are efforts to adopt the use of GIS and remote sensing. In Nigeria, the Federal Government took a bold decision in 2003 to embark on complete computerization of the cadastral and land registry of the Federal Capital Territory (FCT) - Abuja. This decision led to the establishment of an agency known as Abuja Geographic Information Systems (AGIS). Some State Governments are also trying to do the same. A number of Government parastatals are also introducing 
GIS unit/department into their organization. In 1999, Federal Government established the National Space Research and Development Agency (NARSDA) to pursue the development and application of space science and technology for the socio-economic benefits of the nation. In addition six centres were created to act as the operational limbs of the National Space Research and Development Agency (NARSDA). Also in Nigeria, there are some private firms and government institutions offering consultancy and training in GIS and remote sensing (Asiyanbola, 2014; Akingbade and Keita, 2016). In recent time, there have been an increasing number of researchers and publications on remote sensing in Nigeria (Asiyanbola, 2014). Studies in other African countries such as South Africa indicate that Geographical Information Science (GISc) is widely included in South African tertiary degree programmes related to the environmental balance dimension of sustainable development (Coetzee et al., 2013). Nevertheless, there has not been full adoption, implementation and use of remote sensing/GIS in Nigeria (Asiyanbola and Adeoye, 2013; Fabiyi, 2001).

According to Campbell and Masser (1995) diffusion is an umbrella concept which has elements including awareness, adoption, and utilization. Awareness mean ' knowing something', ' 'noticing or realizing something', or ''knowledgeable about something', Adoption mean “choose and decide to use something', while utilization mean ''make use of something', The difference between adoption and utilization is shown in the argument of Campbell and Masser (1995) that the purchase of innovation is no guarantee that the equipment that has been acquired will actually be utilized. As observed in the literature (Heywood et al., 2006), successful application of large-scale geospatial technology projects such as GIS/remote sensing, depends not only on technical aspects, but also on human and organizational factors relating to the implementation and management of systems. This according to Heywood et al., (2006) has been recognized since the 1970s (Tomlinson et al., 1976) and there has been considerable research into the human and organizational factors that may impede the implementation of GIS (Department of the Environment, 1987; Onsrud and Pinto, 1991; Medyckyj-Scott and Hearnshaw, 1994; Campbell and Masser, 1995; Hernandez et al., 1999). As revealed in the literature propensity of individuals or organizations to adopt a particular technology is important for successful application. In fact the literature reveals that personal, organizational and even cultural interests are important in successful adoption of GIS/remote sensing technology (Campbell and Masser, 1995; Kurwakumire, 2014).

Kurwakumire (2014) in his discussion on social constructivist perspective of technology notes that, to understand the technology, it is important to identify relevant social groups or social actors who interact with the technology. He proposed a benefit oriented approach to GIS evaluation which is a mechanism for measuring the success derived from implementing GIS. In his study he observed that GIS develops from grass-root, intermediate, mature to integrated systems. For GIS/remote sensing to migrate to full development stage there is the need to assess the human issues associated with the GIS/remote sensing technologies adoption and utilization with a view to enhancing human capital development in geospatial technologies. This study examines empirically some of the human issues associated with the GIS/remote sensing in Nigeria. Study that examines human issues associated with the GIS/remote sensing is rare in Nigeria. 
Thus, the present study is an addition to the literature and focuses on assessing public servants' GIS/remote sensing awareness and use in Nigeria. Among the research questions which the study addresses are: How is public servants knowledge of the computer? How is public servants interest in GIS/remote sensing training/retraining programmes? How is public servants awareness of GIS/remote sensing benefits and costs? What are the public servants constraints in building their knowledge of GIS/remote sensing? What are the factors that influence/affect the adoption/implementation/use of GIS/remote sensing in the organization? How is the relationship between the working experience and age of public servants and their (i) interests, (ii) awareness, and, (iii) utilization of GIS/remote sensing? Is there significant difference in the public servants (i) awareness, (ii) interests in GIS/remote sensing training/retraining programmes, and, (iii) utilization of GIS/remote sensing. What are the suggestions of the public servants towards improving awareness and use of GIS/remote sensing in the organization and in Nigeria in general? The paper is divided into four sections. The first section is this introduction. The second section is the method of study; the third section is the findings of the study, while the last section is the summary and conclusion.

\section{Method of the study}

The data used in the study was obtained from primary and secondary sources. The primary data was collected through administration of questionnaires. Among the information collected through the questionnaire are: the socio-economic characteristics of the respondents, computer literacy and interest of the respondents in GIS/remote sensing, use of GIS/remote sensing images/software, awareness of the benefits and costs of GIS/remote sensing, factors that influence/affect the use of GIS/remote sensing in respondents' organization, problems affecting respondents use of GIS/remote sensing applications and respondents' suggestions towards improving the use of GIS/remote sensing in their organization and in Nigeria in general. A total of one hundred and one (101) questionnaires were administered to public servants most of whom are in environmental related profession such as town planning, architecture, estate management, surveying, etc. in five local governments in Ibadan metropolitan area and at the Oyo State Government Secretariat in Ibadan between August and October, 2015. The name of the government establishments where the respondents are working and some of the functions/activities the establishment are shown in Appendix 1. Purposeful sampling method was used in the administration of the questionnaires. The data was analyzed using frequencies, descriptive and inferential statistics such as Kolmogorov-Simirnov Test, Chi-Square test and correlation statistical methods to test the stated hypotheses. These nonparametric tests statistics were used because of the nature of the data used in the study.

\section{Findings and discussion}

\subsection{Socio-economic characteristics of the respondents}

The result of the analysis of the socio-economic characteristics of the public servants interviewed shows that $68 \%$ were male while $32 \%$ were female. The mean age of the respondents was 39 years. The majority (87\%) of the respondents were married. The majority of the respondents were 
diploma/degree certificate holders in various areas of specialization which included Urban and Regional Planning, Geography, Transport, Environmental Management, Architecture, Estate Management, Surveying, Quantity Surveying, Civil Engineering, Geology, etc. The mean years of respondents working experience was 14 years.

\subsection{Computer literacy and interest in GIS/Remote Sensing}

Respondents were asked some questions relating to computer literacy and interest in GIS and remote sensing. Table 1 shows the result of the analysis of the response of the respondents.

Table 1: Computer literacy and interest in GIS/Remote Sensing

\begin{tabular}{|c|c|c|c|}
\hline $\mathbf{S} / \mathbf{N}$ & $\begin{array}{l}\text { Computer literacy and interest in } \\
\text { Remote Sensing/GIS }\end{array}$ & Response & $\%(n=101)$ \\
\hline \multirow[t]{2}{*}{1} & Are you computer literate? & Yes & 86.0 \\
\hline & & No & 14.0 \\
\hline \multirow[t]{2}{*}{2} & Do you own personal & Yes & 69.0 \\
\hline & computer/laptop? & No & 31 \\
\hline \multirow[t]{2}{*}{3} & Have you ever attended any & Yes & 29.0 \\
\hline & $\begin{array}{l}\text { GIS/Remote Sensing } \\
\text { training/retraining programme? }\end{array}$ & No & 71 \\
\hline \multirow[t]{2}{*}{4} & Who is responsible for the finance of & Self & 9.0 \\
\hline & $\begin{array}{l}\text { your training in GIS/Remote } \\
\text { Sensing? }\end{array}$ & The Organization & 4.0 \\
\hline \multirow[t]{2}{*}{5} & When you were in school were you & Yes & 55.0 \\
\hline & $\begin{array}{l}\text { taught any GIS/Remote Sensing } \\
\text { course? }\end{array}$ & No & 45.0 \\
\hline \multirow[t]{2}{*}{6} & Do you have interest in GIS/Remote & Yes & 77.0 \\
\hline & Sensing? & No & 23.0 \\
\hline \multirow[t]{6}{*}{7} & What are the constraints you have in & Financial constraint & 58.0 \\
\hline & building your knowledge in & Time constraint & 60.0 \\
\hline & GIS/Remote Sensing? & Lack of interest & 21.0 \\
\hline & & Lack of permission from the place of work & 44.0 \\
\hline & & Lack of access to computer & 18.0 \\
\hline & & Others & 1.0 \\
\hline \multirow[t]{2}{*}{8} & Do you have interest in GIS/Remote & Yes & 80.0 \\
\hline & $\begin{array}{l}\text { Sensing training/retraining } \\
\text { programmes? }\end{array}$ & No & 20 \\
\hline \multirow[t]{6}{*}{9} & What do you think are your constrain & Financial constraint & 60.0 \\
\hline & in attending GIS/Remote Sensing & Time constraint & 63.0 \\
\hline & training/retraining programmes? & Lack of interest & 20.0 \\
\hline & & Lack of permission from the place of work & 42.0 \\
\hline & & Lack of access to computer & 17.0 \\
\hline & & Others & 0.0 \\
\hline
\end{tabular}

Source: Field survey, 2015

Table 1 shows that $86 \%$ of the respondents were computer literate and $69 \%$ of them had their own personal computer/laptop. When asked whether they had ever attended any GIS/Remote sensing training/retraining programme, $71 \%$ of them had never, while $29 \%$ said yes. Most of those that said yes they have attended GIS/remote sensing training/retraining programme said that they sponsor themselves for the training/retraining programme they have attended. In response to the question as to whether the respondents were taught any GIS/remote sensing course when they were in school, most of the respondents (55\%) said yes, while $45 \%$ said no. 
Respondents were asked whether they had interest in GIS/remote sensing. The result of the analysis of the response shows that majority (77\%) of the respondents had interest in GIS/remote sensing. When asked about the constraints they have in building their knowledge in GIS/Remote Sensing, the result shows that time constraint (60\%), financial constraint (58\%) and lack of permission from the place of work (44\%) were the top three constraints they encountered. Respondents were probed further as to whether they has interest in GIS/Remote Sensing training/retraining programmes. The result shows that majority (80\%) of the respondents had interest in GIS/remote sensing training/retraining programmes. Again, when asked what they thought were their constraints in attending GIS/remote sensing programme, the result of their response shows that time constraint (63\%), financial constraint (60\%), and lack of permission from the place of work (42\%) were the top three constraint they encountered.

\subsection{Use of Remote Sensing/GIS images/software}

Respondents were asked various questions relating to their use of remote sensing/GIS images/software. Table 2 shows the results of the analysis of their response.

Table 2: Use of Remote Sensing/GIS images/software

\begin{tabular}{|c|c|c|c|}
\hline $\mathbf{S} / \mathbf{N}$ & $\begin{array}{l}\text { Respondents use of } \text { Remote } \\
\text { images/software }\end{array}$ & Response & $\%(n=101)$ \\
\hline \multirow[t]{2}{*}{1} & \multirow[t]{2}{*}{ Have you use any Remote Sensing images before? } & Yes & 30.0 \\
\hline & & No & 70.0 \\
\hline \multirow[t]{8}{*}{2} & \multirow{8}{*}{$\begin{array}{l}\text { Which GIS/Remote Sensing software have you heard } \\
\text { about or know about? }\end{array}$} & ILWIS & 1.0 \\
\hline & & Arcview 3 & 17.0 \\
\hline & & ArcGIS 9 & 9.0 \\
\hline & & ArcGIS 10 & 1.0 \\
\hline & & ERDAS IMAGINE & 4.0 \\
\hline & & Idrisi & 16.0 \\
\hline & & ENVI & 3.0 \\
\hline & & Others & 0.0 \\
\hline \multirow[t]{9}{*}{3} & \multirow{9}{*}{$\begin{array}{l}\text { Which of the following GIS/Remote sensing software } \\
\text { have you used before? }\end{array}$} & ILWIS & 2.0 \\
\hline & & Arcview 3 & 14.0 \\
\hline & & ArcGIS 9 & 10.0 \\
\hline & & ArcGIS 10 & 2.0 \\
\hline & & ERDAS IMAGINE & 0.0 \\
\hline & & Idrisi & 7.0 \\
\hline & & ENVI & 3.0 \\
\hline & & Others & 0.0 \\
\hline & & None & 4.0 \\
\hline \multirow[t]{2}{*}{4} & \multirow{2}{*}{$\begin{array}{l}\text { Is your department/organization actively using the } \\
\text { GIS/Remote Sensing applications/software? }\end{array}$} & Yes & 9.0 \\
\hline & & No & 91.0 \\
\hline \multirow[t]{2}{*}{5} & \multirow[t]{2}{*}{ Do you have any GIS expert in this Organization? } & Yes & 10.0 \\
\hline & & No & 90.0 \\
\hline
\end{tabular}

Source: Field survey, 2015

Table 2 shows that $70 \%$ of the respondents had never use any remote sensing images before. Some of the respondents said that they have heard of some of the remote sensing/GIS software such as Arcview 3 (17\%), Idrisi (16\%), ArcGIS 9 (9\%), Erdas Imagine (4.0\%), ENVI (3.0\%), ILWIS (1.0\%), and ArcGIS 10 (1.0\%). Some of the respondents said that they have used some of the remote sensing/GIS software such as Arcview 3 (14\%), ArcGIS 9 (10\%), Idrisi (7\%), ENVI (3.0\%) and 
ILWIS (2.0\%). When asked whether their department/organization are actively using the GIS/Remote Sensing applications/software, majority (91\%) of the respondents said no. Also when asked whether they have GIS experts in their organization, majority (90\%) of the respondents said no.

\subsection{Awareness of the benefits of GIS and Remote Sensing}

Respondents were asked questions relating to their awareness of the various benefits of GIS/remote sensing. Table 3 shows the results of the analysis of the respondent awareness of the benefits of GIS/remote sensing.

Table 3: What are the benefits of GIS you are aware of?

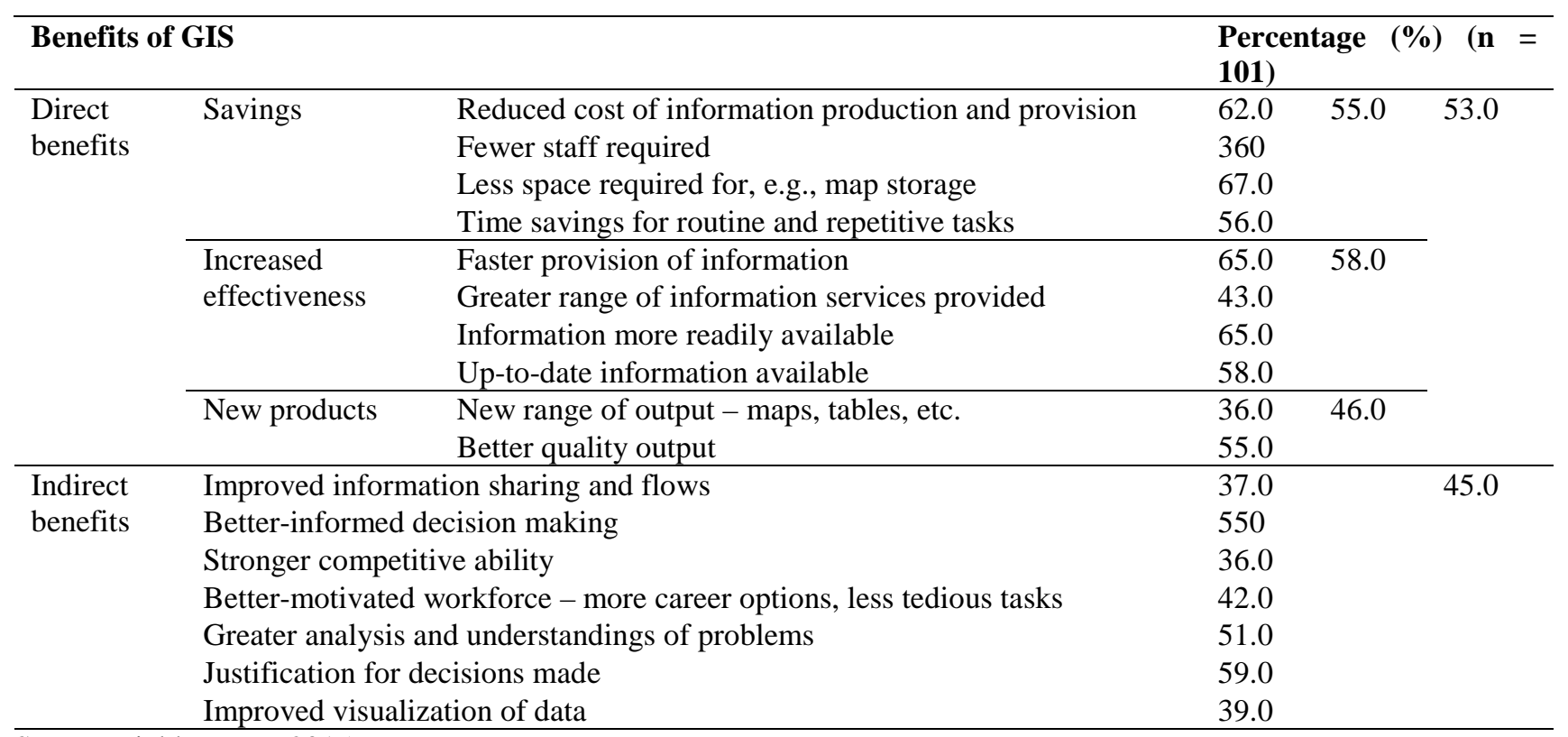

Source: Field survey, 2015

Table 3 shows that most of the respondents were aware of the direct benefits of GIS/remote sensing such as increased effectiveness (faster provision of information, [65\%], information more readily available [65\%], up-to-date information available [58\%]), savings (less space required for, e.g., map storage [67\%], time savings for routine and repetitive tasks [56\%]) and new products (new range of output - maps, tables, etc. [36\%], better quality output [55\%]). Also, most of the respondents were aware of the indirect benefits of GIS/remote sensing such as justification for the decision made (59\%), better-informed decision making (55\%), and greater analysis and understanding of problems (51\%). Generally, the results shows that respondents were more aware of the direct benefits of GIS/remote sensing (53\%) compared to their awareness of the indirect benefits (45\%).

\subsection{Awareness of the costs of GIS/Remote sensing}

Respondents were also asked questions relating to their awareness of the various costs of GIS/remote sensing. The result of the analysis shows that respondents were aware of both direct costs (31\%) and indirect costs (30\%) of GIS/remote sensing. Top on the list of the direct costs that respondents were aware of was human/administration cost (37\%), followed by hardware/software cost (36\%), data cost (28\%) and methods for choosing systems cost (23\%). In the case of indirect 
costs, the top three costs respondents were aware of were increased reliance on computers vulnerability to failures, changes in software/hardware, etc. (35\%), poorer working environment noise, heat, tedious tasks for users (31\%) and higher-skilled workforce required (25\%).

The results of the analysis further show that respondents were more aware of the benefits of remote sensing/GIS than the costs of GIS/remote sensing. While $53 \%$ of the respondents were aware of the direct benefits of GIS/remote sensing, 31\% were aware of the direct costs. Also while $45 \%$ were aware of the indirect benefits of GIS/remote sensing, 30\% were aware of the indirect costs.

\subsection{Factors that influence/affect the adoption/implementation/use of GIS/Remote Sensing in the respondents' organization}

Respondents were asked questions relating to various factors that influence/affect the adoption/implementation/use of GIS/remote sensing in the respondents' organization. The results of the analysis shows that the three top factors that influences/affects the adoption/implementation/use of GIS/remote sensing in the respondents' organization were compatibility and past success (46\%), ease of use (45\%) and cost (44\%). Top on the list of the factor under compatibility and past success was the extent of computer usage skill (58\%) followed by the history of successful computer systems in the organization (34\%). In the case of ease of use, top factor under this was availability of GIS/remote sensing skilled people (55\%), followed by availability of existing data (50\%) and compatibility of GIS/remote sensing with existing computer system (40\%). Also the top factor under cost was retraining staff cost (55\%), cost of hardware and software (50\%) and cost of data entry (41\%).

\subsection{Problems affecting use of GIS/Remote Sensing applications}

Table 4 shows the response of the respondents to the question on the problems affecting their use of GIS/remote sensing applications.

Table 4: What are the problems affecting your use of GIS/Remote Sensing applications?

\begin{tabular}{ll}
\hline Response & $\begin{array}{l}\text { Percentage (\%) } \\
(\mathbf{n}=\mathbf{1 0 1})\end{array}$ \\
\hline Lack of knowledge about it & 75.0 \\
Technical nature of the applications & 65.0 \\
Financial problems & 86.0 \\
Lack of incentives/motivation & 66.0 \\
Power supply (electricity) problem & 79.0 \\
Lack of interest & 34.0 \\
Others & 1.0 \\
\hline
\end{tabular}

Source: Field survey, 2015 
Table 4 shows that financial problems (86\%) is top on the list, followed by power supply (electricity) problem (79\%), lack of knowledge about GIS/remote sensing applications (75\%), lack of incentives/motivation (66\%), technical nature of the applications (65\%), and lack of interest (34\%).

\subsection{Results of the test of the hypotheses}

\subsubsection{Hypothesis 1}

How is the relationship between the working experience and age of public servants and their (i) interests, (ii) awareness, and, (iii) utilization of GIS/remote sensing?

Socio-economic variables indicates a person's characteristics and status. This hypothesis was to examine if there was significant relationship between public servants characteristics as measured by age and working experience and their (i) interests in GIS/remote sensing training/retraining programme, (ii) awareness of the benefits and costs of GIS/remote sensing, and, (iii) utilization of GIS/remote sensing. Interest was measured in the study as 'if interested 1 otherwise 0', awareness was measured as "'if aware 1 otherwise 0", utilization of GIS/remote sensing was measured as "if respondents had ever used remote sensing images 1 otherwise 0", age and working experience were measured in years. Table 5 shows the results of the correlation (Spearman's rho) statistical analysis.

Table 5: Result of the correlation (Spearman's rho) statistical analysis

\begin{tabular}{|c|c|c|c|c|c|c|}
\hline & $\begin{array}{l}\text { Age } \\
\text { (in years) }\end{array}$ & $\begin{array}{l}\text { Interest in } \\
\text { GIS/Remo } \\
\text { te Sensing }\end{array}$ & $\begin{array}{l}\text { Utilization of } \\
\text { GIS/Remote } \\
\text { Sensing }\end{array}$ & $\begin{array}{l}\text { Working } \\
\text { experience } \\
\text { (in years) }\end{array}$ & $\begin{array}{l}\text { Awareness of } \\
\text { the benefits }\end{array}$ & $\begin{array}{l}\text { Awareness of } \\
\text { the costs }\end{array}$ \\
\hline Age & 1.000 & .018 & -.037 & $.446^{* *}$ & -.102 & -.090 \\
\hline $\begin{array}{l}\text { Interest } \\
\text { GIS/Remote } \\
\text { Sensing }\end{array}$ & .018 & 1.000 & $.250 *$ & -.138 & $.209 *$ & .142 \\
\hline $\begin{array}{l}\text { Utilization of } \\
\text { GIS/Remote } \\
\text { Sensing }\end{array}$ & -.037 & $.250 *$ & 1.000 & -.001 & $.510 * *$ & $.435^{* * *}$ \\
\hline $\begin{array}{l}\text { Working } \\
\text { experience (in } \\
\text { years) }\end{array}$ & $.446^{* *}$ & -.138 & -.001 & 1.000 & -.092 & .109 \\
\hline $\begin{array}{l}\text { Awareness of the } \\
\text { benefits }\end{array}$ & -.102 & $.209 *$ & $.510 * *$ & -.092 & 1.000 & $.548 * *$ \\
\hline $\begin{array}{l}\text { Awareness of the } \\
\text { costs }\end{array}$ & -.090 & .142 & $.435^{* *}$ & .109 & $.548 * *$ & 1.000 \\
\hline
\end{tabular}

Source: Field survey, 2015

${ }^{* *}$ Correlation is significant at the 0.01 level (2-tailed)

*Correlation is significant at the o.05 level (2-tailed)

Table 5 shows that there was no significant relationship between the working experience of the respondents and interest in GIS/remote sensing, awareness of the benefits and cost, and utilization of GIS/remote sensing. The results also show that there was no significant relationship between the age 
of the respondents and interest in GIS/remote sensing, awareness of the benefits and costs, and utilization of GIS/remote sensing.

\subsubsection{Hypothesis 2}

Is there significant difference in the public servants (i) awareness, (ii) interests in GIS/remote sensing training/retraining programmes, and, (iii) utilization of GIS/remote sensing. KolmogorovSimirnov Test and Chi-Square were used to test hypothesis two. Table 6 shows the results of the test.

Table 6: Results of test of hypothesis two (2)

\begin{tabular}{|c|c|c|c|c|}
\hline Null Hypotheses & Test & & Sig. & Decision \\
\hline $\begin{array}{l}\text { There is no significant difference among the public servants that } \\
\text { are aware of the benefits of GIS/remote sensing }\end{array}$ & $\begin{array}{l}\text { One-Sample } \\
\text { Kolmogorov- } \\
\text { Simirnov Test }\end{array}$ & & .234 & $\begin{array}{l}\text { Retain the } \\
\text { null } \\
\text { hypothesis }\end{array}$ \\
\hline $\begin{array}{l}\text { There is no significant difference among the public servants that } \\
\text { are aware of the costs of GIS/remote sensing }\end{array}$ & $\begin{array}{l}\text { One-Sample } \\
\text { Kolmogorov- } \\
\text { Simirnov Test }\end{array}$ & & .287 & $\begin{array}{l}\text { Retain the } \\
\text { null } \\
\text { hypothesis }\end{array}$ \\
\hline $\begin{array}{l}\text { There is no significant difference among the public servants who } \\
\text { have interest in GIS/Remote Sensing training/retraining } \\
\text { programme }\end{array}$ & $\begin{array}{l}\text { One-Sample } \\
\text { Square }\end{array}$ & Chi- & .000 & $\begin{array}{l}\text { Reject the } \\
\text { null } \\
\text { hypothesis }\end{array}$ \\
\hline $\begin{array}{l}\text { There is no significant difference among the public servants who } \\
\text { have used remote sensing images }\end{array}$ & $\begin{array}{l}\text { One-Sample } \\
\text { Square }\end{array}$ & Chi- & .000 & $\begin{array}{l}\text { Reject the } \\
\text { null } \\
\text { hypothesis }\end{array}$ \\
\hline
\end{tabular}

Source: Field survey, 2015

Table 6 shows that there was no significant difference among the public servants that were aware of the benefits and costs of GIS/remote sensing; there was significant difference among the public servants who had interest in GIS/remote sensing training/retraining programme; and there was significant difference among the public servants who had used remote sensing images.

\subsection{Respondents' suggestions towards improving awareness and use of GIS/remote sensing in the organization and in Nigeria in general}

Respondents were asked their suggestions towards improving awareness and use of GIS/remote sensing in the organization and in Nigeria in general. Table 7 shows respondents' suggestions towards improving awareness and use of GIS/remote sensing in their organization and in Nigeria in general. 
Table 7: What are your suggestions towards improving awareness and use of GIS/remote sensing in the organization and in Nigeria in general?

\begin{tabular}{ll}
\hline Suggestions & Percentage (\%) (n = 101) \\
\hline Public sensitization/enlightenment & 34.0 \\
Making computer available at affordable rate by the government & 17.0 \\
Organization of workshops and seminars & 24.0 \\
Injection of GIS into the curriculum of school right from secondary school & 5.0 \\
Procurement of latest software & 4.0 \\
Scholarships for interested staff & 15.0 \\
Employment of GIS experts & 4.0 \\
Provision of adequate and stable power supply & 5.0 \\
$\begin{array}{l}\text { GIS trainers should reduce the cost of training to attract more participants } \\
\text { Others (e.g., Training and retraining of staff; Making GIS training easy to access; }\end{array}$ & 4.0 \\
$\begin{array}{l}\text { Creation of enabling environment; Every organization should be equipped with } \\
\text { computers; GIS/Remote sensing should be made compulsory to all science and } \\
\text { environmental base personnel as an additional qualification; Government should } \\
\text { encourage people; }\end{array}$ & \\
\hline
\end{tabular}

Source: Field survey, 2015

Table 7 shows that top on the list of respondents' suggestions towards improving awareness and use of GIS/remote sensing in the organization and in Nigeria in general was public sensitization/enlightenment, followed by organizations of workshops and seminars. Others were making computers available at affordable rate by the government, scholarship for interested staff, training and retraining of staff; making GIS/remote sensing training easy to access, creation of enabling environment, every organization should be equipped with computers, GIS/remote sensing should be made compulsory to all science and environmental base personnel as an additional qualification, government should encourage people, including GIS/remote sensing in the curriculum of school right from secondary school, provision of adequate and stable power supply and that GIS trainers should reduce the cost of training to attract more participants.

\section{Summary and conclusion}

This paper has carried out an evaluation of public servants' awareness and use of Remote Sensing/GIS in Ibadan, Oyo State, Nigeria. The findings include: majority of the public servants were computer literate and had interest in GIS/remote sensing; they were more aware of the benefits than the costs of GIS/remote sensing; time, finance, and lack of permission from the place of work were the three top constraints in building their GIS/remote sensing knowledge; compatibility and past success, ease of use, and cost were the three top factors that influence/affect the use of GIS/remote sensing in their organization. Top on the list of problems affecting respondents' use of GIS/Remote Sensing applications was financial problems, followed by power supply (electricity) problem, lack of knowledge about GIS/Remote Sensing applications, lack of incentives/motivation, technical nature of the applications, and lack of interest. 
The results of the correlation (Spearman's rho) statistical analysis shows that there was no significant relationship between the working experience of the respondents and interest in GIS/remote sensing, awareness of the benefits and cost, and utilization. The results also show that there was no significant relationship between the age of the respondents and interest in GIS/remote sensing, awareness of the benefits and costs, and utilization of GIS/remote sensing. The results of Kolmogorov-Simirnov Test and Chi-Square shows that there was no significant difference among the public servants that were aware of the benefits and costs of GIS/remote sensing; there was significant difference among the public servants who had interest in GIS/Remote Sensing training/retraining programme; and there was significant difference among the public servants who had use remote sensing images. Top on the list of respondents' suggestions towards improving the use of GIS/remote sensing in their organization and in Nigeria in general was public sensitization/enlightenment, followed by organizations of workshops and seminars, making computers available at affordable rate by the government, and, provision of scholarship for interested staff, training and retraining of staff; making GIS/remote sensing training easy to access, creation of enabling environment, every organization should be equipped with computers, GIS/remote sensing should be made compulsory to all science and environmental base personnel as an additional qualification, government should encourage people, including GIS/remote sensing in the curriculum of school right from secondary school, provision of adequate and stable power supply and that GIS/remote sensing trainers should reduce the cost of training to attract more participants.

As observed in the literature successful technology-led innovation depends not only on proper organizational/management support and infrastructure but also on culture, that is, propensity of individuals to adopt a particular technology (Campbell and Masser, 1995; Heywood et al., 2006). Kurwakumire (2014) in his study observed that GIS develops from grass-root, intermediate, mature to integrated systems. Presently, there has not been full development of GIS/remote sensing in Nigeria. For GIS/remote sensing to migrate to full development stage there is the need for development of human capital in geospatial technologies. Originating from the findings of this study and in order to enhance human capacity development in geospatial technologies, there is the need for implementing policies that will increase the propensity of public servants' use of GIS/remote sensing. There is the need for government to provide stimulating and enabling environment that will encourage increase interest in GIS/remote sensing in Nigeria in general. Such expected actions include provision of financial support for the public servants for training and retraining programmes in GIS/remote sensing. There is also the need for the provision of necessary facilities and equipment that will increase the use of GIS/remote sensing technologies.

\section{Acknowledgement:}

The earlier version of this paper was presented at the $11^{\text {th }}$ International Conference of the African Association of Remote Sensing of the Environment (AARSE) held in Kampala, Uganda $24^{\text {th }}-28^{\text {th }}$ October 2016. The author wishes to appreciate the effort of Mr. Akinola Ishaq Enitan a doctoral student in the Department of Urban and Regional Planning, University of Ibadan, Ibadan, Nigeria, 
who assisted in the field survey. The author also wishes to thank Dr. N.O. Adeoye, Department of Geography Obafemi Awolowo University, Ile-Ife, Osun State, Nigeria, for his useful comments on the questionnaire administered to collect the data.

\section{References}

Ademola A., 2015, ‘Geographic Information System’ in Layi Egunjobi (eds.) Contemporary Concepts in Physical Planning Vol 1, Department of Urban and Regional Planning, University of Ibadan, Ibadan. Pp. $473-496$.

Akingbade A.O. \& Keita M.S., 2016, ‘Capacity building in Geospatial Science and Technology in West Africa: Opportunities, Challenges and Prospects'. A paper presented at the 11th International Conference of AARSE, held in Kampala, Uganda, $24^{\text {th }}-28^{\text {th }}$ October 2016.

Asiyanbola R.A., 2014, 'Remote Sensing Education and Research situation in Nigeria: An Overview towards enhancing capacity building', in Fethi Ahmed, Onisimo Mutanga, and Elisabeth Zeil-Fahlbusch (eds.) Space Technologies for Societal Benefits in Africa. Proceedings of the 10th International Conference of AARSE, October 2014, pp. 470 - 492

Asiyanbola R.A. \& Adeoye N.O, 2013, “The diffusion of Geograohic Information Systems Knowledge and Technology in Nigeria: an exploration”. Journal of Earth Science and Engineering 1:50-56

Bamutaze Y., 2014, 'Geo-capacity building: A panacea for transformative and resilient societal development in Africa?' A keynote presentation at the $10^{\text {th }}$ International Conference of the African Association of Remote Sensing of the Environment held at the University of Johannesburg, South Africa, $27^{\text {th }}-31^{\text {st }}$ October, 2014.

Campbell H.J. \& Masser I., 1995, GIS and Organizations: How effective are GIS in practice? Taylor and Francis, London.

Coetzee S., Eksteen S. \& Grundling C. 2013, 'Sustainable Development: The contribution from GISc education in South Africa’, South African Journal of Geomatics, Vol. 2, No. 3, pp. 246-259

Dangermond J., 2011, 'GIS: A language for understanding'. A keynote presentation at the 2011 ESRI International User Conference in San Diego, California, July 11-15, 2011 ARCNEWS Esri Fall Vol. 33, No. 3 p. $1,7$.

Department of the Environment 1987, Handling Geographic Information. Report of the Committee of Enquiry Chaired by Lord Chorley. HMSO, London

ESRI 2006, GIS Solutions for Urban and Regional Planning: Designing and Mapping the Future of your Community with GIS. www.esri.com

Fabiyi S., 2001, Geographic Information Systems: Techniques and Methods. Research Support Services, Ibadan, Nigeria

Hernandez T., Scholten H.J., Bennison D., Biasiotto M., Cornelius S., \& van der Beek M., 1999, 'Explaining retail GIS: the adoption, use and development of GIS by retail organizations in the Netherlands, the UK and Canada'. Netherlands Geographical Studies 258 Utrecht

Heywood Ian, Cornelius Sarah \& Carver Steve (eds.) 2006, An Introduction to Geographical Information Systems. Pearson Education Limited, England 
Inggs M. 2014, 'Space Technology for Societal Benefits in Africa'. A keynote presentation at the $10^{\text {th }}$ International Conference of the African Association of Remote Sensing of the Environment held at the University of Johannesburg, South Africa, 27 $7^{\text {th }}-31^{\text {st }}$ October, 2014.

Keita M.S., 2014, 'Geospatial Technology for Sustainable Development in Africa - Lessons from Development Projects in West Africa'. A keynote presentation at the $10^{\text {th }}$ International Conference of the African Association of Remote Sensing of the Environment held at the University of Johannesburg, South Africa, $27^{\text {th }}-31^{\text {st }}$ October, 2014.

Kurwakumire E., 2014. 'Towards a Public Sector GIS Evaluation Methodology’. South African Journal of Geomatics, Vol. 3, No. 1, pp. 33 - 52

Medyckyj-Scott D.J. \& Hearnshaw H.M., 1994, Human factors in Geographical Information Systems. Belhaven, London.

Mhangara P. \& Odindi J.O. 2013, 'Opportunities for increasing societal value of remote sensing data in South Africa’s strategic development priorities: A review’, South African Journal of Geomatics, Vol. 2, No. 1, pp. 28-40

Murwira A., 2014, 'Research and development is key to accelerating societal benefits of space technologies in Africa'. A keynote presentation at the $10^{\text {th }}$ International Conference of the African Association of Remote Sensing of the Environment held at the University of Johannesburg, South Africa, $27^{\text {th }}-31^{\text {st }}$ October, 2014.

Olwoch J., 2014, 'From Space to Society'. A keynote presentation at the $10^{\text {th }}$ International Conference of the African Association of Remote Sensing of the Environment held at the University of Johannesburg, South Africa, $27^{\text {th }}-31^{\text {st }}$ October, 2014.

Onsrud H.J., \& Pinto J.K., 1991, Diffusion of Geographic innovations. International Journal of Geographical Information Systems 5(4): 447-467

Tomlinson R.F., Calkins H.W. \& Marble D.F., 1976, Computer Handling of Geographic Data. UNESCO Press Paris.

Woldai T., 2014, ‘The benefit and application of Earth Observation'. A keynote presentation at the $10^{\text {th }}$ International Conference of the African Association of Remote Sensing of the Environment held at the University of Johannesburg, South Africa, 2 


\section{Appendix 1: Name of government establishment and their functions/activities}

\begin{tabular}{|c|c|}
\hline $\begin{array}{l}\text { Name of government } \\
\text { establishment }\end{array}$ & Functions/Activities \\
\hline Local Governments & \\
\hline $\begin{array}{l}\text { Ibadan North Local } \\
\text { Government Zonal Planning } \\
\text { Office } \\
\text { Ibadan North East Local } \\
\text { Government Zonal Planning } \\
\text { Office } \\
\text { Ibadan North West Local } \\
\text { Government Zonal Planning } \\
\text { Office } \\
\text { Ibadan South East Local } \\
\text { Government Zonal Planning } \\
\text { Office } \\
\text { Ibadan South West Local } \\
\text { Government Zonal Planning } \\
\text { Office }\end{array}$ & $\begin{array}{l}\text { Development Control; Site Inspection; Handling of petition and complaint } \\
\text { within Local Government Jurisdiction; Offering reasonable advise to } \\
\text { prospective site developer; Ensuring compliance with planning laws and } \\
\text { regulations; Zoning; Plan registration, Charting and Coordination; } \\
\text { Production of subject , rural, and town plans; Involvement in Street naming; } \\
\text { Public enlightenment on Town Planning matters }\end{array}$ \\
\hline $\begin{array}{l}\text { Ibadan North Local } \\
\text { Government Works } \\
\text { Department } \\
\text { Ibadan North East Local } \\
\text { Government Works } \\
\text { Department } \\
\text { Ibadan North West Local } \\
\text { Government Works } \\
\text { Department } \\
\text { Ibadan South East Local } \\
\text { Government Works } \\
\text { Department } \\
\text { Ibadan South West Local } \\
\text { Government Works } \\
\text { Department }\end{array}$ & $\begin{array}{l}\text { Building condition survey; Building maintenance; Design and construction } \\
\text { of projects; Inspection of all projects carried out by contractors; Supervision } \\
\text { of Projects; Monitoring of Projects; Construction of roads and culverts; } \\
\text { Construction of Buildings }\end{array}$ \\
\hline
\end{tabular}

\begin{tabular}{ll}
\hline Ibadan North Local & $\begin{array}{l}\text { Monitor all leases; Monitor illegal contravention in the local government; } \\
\text { Government Estate }\end{array}$ \\
$\begin{array}{l}\text { Collection of ground rent; Management and maintenance of government } \\
\text { properties; Collection of tenement rate; Supervision of Local Government }\end{array}$ \\
$\begin{array}{l}\text { Ibadan North East Local } \\
\text { Government Estate }\end{array}$ & $\begin{array}{l}\text { landed properties; Land allocation; Allocation of Shops; Management of the } \\
\text { popartment }\end{array}$ \\
Ibadan North West Local & \\
Government Estate & \\
Department & \\
Ibadan South East Local & \\
Government Estate & \\
Department & \\
Ibadan South West Local & \\
Government Estate & \\
Department &
\end{tabular}

\begin{tabular}{ll}
\hline Ministry of Physical Planning & Preparation and review of Physical Development plans for various \\
and Urban Development (Oyo & constituent settlements in the State; Preparation and review of \\
State Secretariat) & comprehensive regional, sub-regional, and district plans; Preparation and \\
& review of master/structure plans for Ibadan metropolis and other urban \\
& centres; Formulation of State policies for urban and regional planning; \\
& Initiation and preparation of physical development plans.
\end{tabular}


South African Journal of Geomatics, Vol. 7. No. 1, AARSE 2017 Special Edition, January 2017

\begin{tabular}{ll}
\hline $\begin{array}{l}\text { Name of government } \\
\text { establishment }\end{array}$ & Functions/Activities \\
\hline Local Governments & \\
\hline $\begin{array}{l}\text { Ministry of Land and Survey } \\
\text { (Oyo State Secretariat) }\end{array}$ & $\begin{array}{l}\text { Policy formulation on Land matters in Oyo State; Policy implementation on } \\
\text { Land matters in Oyo State; Land evaluation with regards to Certificate of } \\
\text { Occupancy; Advisory role to the Government on Land matter in Oyo State; } \\
\text { Evaluation of Landed properties; Preparation of bill of quantity }\end{array}$
\end{tabular}

\begin{tabular}{ll}
\hline Ibadan Local Government & Land Allocation; Property Document Processing; Site Inspection; \\
Properties Company Limited & Valuation; Preparation and collection of ground rent
\end{tabular}

Source: Field survey, 2015 